\title{
Long noncoding RNA PCAT-14 induces proliferation and invasion by hepatocellular carcinoma cells by inducing methylation of miR-372
}

\author{
Yawei Wang ${ }^{1}$, Ye $\mathrm{Hu}^{2}$, Gang Wu${ }^{3}$, Ye Yang${ }^{1}$, Yanqing Tang${ }^{4}$, Wanchuan Zhang ${ }^{3}$, \\ Kaiyu Wang ${ }^{3}$, Yu Liu ${ }^{1}$, Xin Wang ${ }^{1}$, Tiemin Li $^{1}$ \\ ${ }^{1}$ Department of Geriatric Surgery, The First Affiliated Hospital of China Medical University, Shenyang, Liaoning 110001, China \\ ${ }^{2}$ Department of Nephrology, Liaoning Provincial People's Hospital, Shenyang, Liaoning 110000, China \\ ${ }^{3}$ Department of General Surgery, The First Hospital Affiliated to China Medical University, Shenyang, Liaoning 110001, China \\ ${ }^{4}$ Department of Psychology, The First Affiliated Hospital of China Medical University, Shenyang, Liaoning 110001, China
}

Correspondence to: Gang Wu, email: 18660232387@163.com

Keywords: PCAT-14, miR-372, HCC, proliferation, invasion

Received: November 30, $2016 \quad$ Accepted: March 08, 2017 Published: March 16, 2017

Copyright: Wang et al. This is an open-access article distributed under the terms of the Creative Commons Attribution License (CC-BY), which permits unrestricted use, distribution, and reproduction in any medium, provided the original author and source are credited.

\section{ABSTRACT}

Long non-coding RNAs (IncRNAs) regulate oncogenesis by inducing methylation of CpG islands to silence target genes. Here we show that the IncRNA PCAT-14 is overexpressed in patients with hepatocellular carcinoma (HCC), and is associated with a poor prognosis after surgery. Our results demonstrate that PCAT-14 promotes proliferation, invasion, and cell cycle arrest in HCC cells. In addition, PCAT-14 inhibits miR-372 expression by inducing methylation of the miR-372 promoter. Simultaneously, miR-372 eliminates the effects of PCAT-14 on proliferation, invasion, and cell cycle in HCC cells. Moreover, PCAT-14 regulates expression of ATAD2 and activation of the Hedgehog pathway via miR-372. These findings indicate that PCAT-14 plays an important role in $\mathrm{HCC}$, and may serve as a novel prognostic factor and therapeutic target.

\section{INTRODUCTION}

Hepatocellular carcinoma (HCC) is one of the most prevalent tumor types with the highest mortality rate [1]. The occurrence of $\mathrm{HCC}$ is increasing, especially in Asia and Africa [2]. Many HCC patients do not have any symptoms until an advanced stage [3]. Even though HCC prognosis has improved thanks to the development of effective surgical techniques and diagnostic methods over recent years, long-term prognosis is still unsatisfactory largely due to the high recurrence $(50-70 \%$ at 5 years) $[4,5]$. Thus, there is an urgent need to identify valuable diagnostic and prognostic biomarkers to improve clinical outcomes and develop effective individual therapeutic strategies for patients with HCC.

Long non-coding RNAs (lncRNAs) are a class of non-coding RNAs that have more than 200 nucleotides (nt) $[6,7]$. With the development of deep sequencing technologies, lncRNAs have increasingly been associated with various human diseases, particularly different types of cancer [8-10]. LncRNAs, such as HULC, HOTAIR, and DBH-AS1 represent an emerging group, which may regulate $\mathrm{HCC}$ cell proliferation, migration, and apoptosis [11-13].
LncRNA prostate cancer-associated transcripts (PCATs) were originally identified as biomarkers for prostate cancer [14]. They include PCAT-1, PCAT-6, PCAT-14, and PCAT-29, which play critical roles in the progression of several cancer types [15-17]. Increased expression of PCAT-1 has been associated with advanced clinical parameters and poor overall survival of $\mathrm{HCC}$ patients [18]. Upregulation of PCAT-1 contributes to HCC cell proliferation, migration, and apoptosis [19]. PCAT-14 is located on chromosome 22, GRCh38.p7. An integrative analysis revealed that PCAT-14 is the most prevalent lncRNA that is aberrantly expressed in prostate cancer patients [20], and predicts a poor outcome [21]. However, the expression and function of PCAT-14 in HCC have not been studied.

In this study, we have analyzed the expression and function of PCAT-14 in HCC. Our results demonstrate that the PCAT-14 expression is associated with HCC metastasis, tumor size, and TNM stage, suggesting that PCAT-14 may be involved in the tumorigenesis and progression of HCC. In addition, Kaplan-Meier and Cox regression analysis shows that high PCAT-14 expression correlates with poor OS, indicating that it could serve as 
an independent prognostic factor for overall survival in HCC. Our results demonstrate that PCAT-14 promotes cellular invasion and proliferation, and inhibits miR-372 expression by inducing methylation of $\mathrm{CpG}$ islands in the miR-372 promoter. In addition, PCAT-14 regulates ATAD2 expression and activation of Hedgehog pathway in HCC cells, depending on miR-372. Together, these results indicate that PCAT-14 plays a critical role in HCC, and may serve as a candidate target for new HCC therapies.

\section{RESULTS}

\section{PCAT-14 expression is increased in HCC tissues and cells}

RT-PCR analysis demonstrated an increased PCAT14 expression in HCC tissues compared with normal tissues $(0.203 \pm 0.204$ vs. $0.099 \pm 0.164$, respectively; $P<0.01)$ (Figure 1G). In situ hybridization of tissues from $120 \mathrm{HCC}$ patients revealed that the PCAT-14 expression was increased in 91 cases $(75.8 \%)$ (Figure 1A-1C). Furthermore, liver LO2 cells had decreased PCAT-14 expression compared to HCC cell lines HepG2, PLC5, QGY7701, HCCLM3, HUH7, and SMMC7721 (Figure 1H).

\section{Clinical significance of PCAT-14 expression in HCC}

According to the results of in situ hybridization, the association between PCAT-14 expression and clinicopathological factors of the $120 \mathrm{HCC}$ patients was analyzed. The expression of PCAT-14 was significantly higher in HCC tissues with advanced TNM stage compared with those with early TNM stage $(P=0.021)$. In addition, the increased PCAT-14 expression was associated with tumor metastasis $(P=0.022)$ and larger tumor size $(P=0.006$, Table 1$)$. The OS was higher in HCC patients with lower PCAT-14 expression than in those with higher PCAT-14 expression ( $P<0.01$, Figure 1I). In addition, a multivariate analysis using the Cox model indicated that PCAT-14 expression, metastasis, and AFP status were independent, poor prognostic factors (Table 2).

\section{PCAT-14 induces cancer cell invasion}

Cell invasion and migration assays demonstrated that SMMC7721 liver cancer cells transfected with pcDNA-lincRNA-PCAT-14 displayed more invasive and migratory properties compared to cells transfected with pcDNA-NC (invasion cells: $55 \pm 8$ VS. $35 \pm 6$, $P<0.01$; migration cells: $77 \pm 9$ vs $53 \pm 6, P<0.01$, Figure 2A). Trans-well chamber assay also showed that downregulation of PCAT-14 by transfected si-lincRNAPCAT-14 in HepG2 cells significantly inhibited their invasion and migration compared with si-NC groups (invasion cells: $27 \pm 9$ VS. $49 \pm 11, P<0.01$;migration cells: $51 \pm 12$ vs $79 \pm 10, P<0.01$, Figure $2 \mathrm{~B}$ ).

\section{PCAT-14 induces cancer cell proliferation}

A significant change in proliferation rate was observed using the MTT assay 72 hours after transfection with pcDNA-PCAT-14 or si-PCAT-14 when compared to pcDNA-NC or si-NC in SMMC7721 and HepG2 cells $(P<0.01$, Figure 6A, 6B). Consistent with the MTT assay, up-regulation of PCAT-14 in SMMC7721 cells increased the number and size of foci (pcDNA-PCAT-14 vs. pcDNA-NC: $184 \pm 18$ vs. $121 \pm 14, P<0.01$, Figure $3 \mathrm{~A}$ ). In contrast, depletion of PCAT-14 in HepG2 cells decreased the number and size of foci (si-PCAT-14 vs. si-NC: $76 \pm 14$ vs. $133 \pm 21, P<0.01$, Figure 3 B). To test whether PCAT-14 could affect the tumorigenicity of HCC cells in vivo, a xenograft model of nude mice was used. Twenty-eight days after the mice were injected with SMMC7721 cells transfected with pcDNA-PCAT-14, the tumor weight was much higher in the cDNA-PCAT-14 group than in the control pcDNA-NC group $(1.54 \pm 0.23 \mathrm{~g}$ vs. $0.68 \pm 0.16 \mathrm{~g}, P<0.01$, Figure $4 \mathrm{~A}$ ). The tumor weight in mice injected with HepG2 cells transfected with siPCAT-14 was lower than in the control si-NC group $(0.48$ $\pm 0.12 \mathrm{~g}$ vs. $1.29 \pm 0.19 \mathrm{~g}, P<0.01$, Figure $4 \mathrm{~B})$. The same phenomenons was observed in HCCLM3 (Figure 4C).

\section{PCAT-14 regulates cancer cell cycle}

The effect of PCAT-14 on the cell cycle was analyzed using flow cytometry analysis. In SMMC7721 cells, PCAT-14 overexpression decreased the number of cells in G1 phase $(40.18 \%)$ and $S$ phase $(27.44 \%)$ compared with the negative control (G1, 56.52\%; S, 20.64\%, Figure 3C). In HepG2 cells, PCAT-14 downregulation increased the number of cells in G1 phase $(62.46 \%)$ and $\mathrm{S}$ phase (21.09\%) compared with the negative control (G1, 43.42\%; S, 29.92\%, Figure 3D). These results suggest that PCAT-14 could affect cell proliferation by regulating the G1/S phase.

\section{Expression of miR-372 negatively correlates with PCAT-14 expression in HCC}

In this study, we used the same HCC samples for qRT-PCR and in situ hybridization as we have previously used for miR-372 analysis [22]. Analysis of HCC samples from 120 patients revealed a negative correlation between PCAT-14 and miR-372 (Figure 1A-1F). There was a significant negative association between PCAT-14 and miR372 analyzed in the same specimens, using the Spearman Rank C test (Table 3, $P<0.01$ ). Consistent with the results of in situ hybridization, miR-372 expression also negatively correlated with PCAT-14 expression by using linear regression analysis of 37 clinical HCC samples analyzed by qRT-PCR $\left(\mathrm{R}^{2}=0.504, P<0.01\right.$, Figure $\left.5 \mathrm{~A}-5 \mathrm{~B}\right)$. 
Table 1: Association between PCAT-14 expression according to in situ hybridization and conventional clinicopathological parameters in 120 patients with $\mathrm{HCC}$

\begin{tabular}{|c|c|c|c|c|}
\hline Characteristics & $\begin{array}{c}\text { Number of } \\
\text { patients }\end{array}$ & $\begin{array}{c}\text { PCAT-14 } \\
\text { Lowexpression }\end{array}$ & $\begin{array}{c}\text { PCAT-14 } \\
\text { Highexpression }\end{array}$ & $\boldsymbol{P}$ \\
\hline & 120 & 29 & 91 & \\
\hline \multicolumn{5}{|l|}{ Age (years) } \\
\hline $\begin{array}{l}\geq 50 \\
<50\end{array}$ & $\begin{array}{l}74 \\
46\end{array}$ & $\begin{array}{l}14(18.9 \%) \\
15(32.6 \%)\end{array}$ & $\begin{array}{l}60(81.1 \%) \\
31(67.4 \%)\end{array}$ & 0.089 \\
\hline \multicolumn{5}{|l|}{ Gender } \\
\hline $\begin{array}{l}\text { Male } \\
\text { Female }\end{array}$ & $\begin{array}{l}51 \\
69\end{array}$ & $\begin{array}{l}16(31.4 \%) \\
13(18.8 \%)\end{array}$ & $\begin{array}{l}35(68.6 \%) \\
56(81.2 \%)\end{array}$ & 0.113 \\
\hline \multicolumn{5}{|l|}{ Tumor size } \\
\hline $\begin{array}{l}\geq 5 \mathrm{~cm} \\
<5 \mathrm{~cm}\end{array}$ & $\begin{array}{l}51 \\
69\end{array}$ & $\begin{array}{l}6(11.8 \%) \\
23(33.3 \%)\end{array}$ & $\begin{array}{l}45(88.2 \%) \\
46(66.7 \%)\end{array}$ & 0.006 \\
\hline \multicolumn{5}{|l|}{ Metastasis } \\
\hline $\begin{array}{l}\text { Yes } \\
\text { No }\end{array}$ & $\begin{array}{l}37 \\
83\end{array}$ & $\begin{array}{l}4(10.8 \%) \\
25(30.1 \%)\end{array}$ & $\begin{array}{l}33(89.2 \%) \\
58(69.1 \%)\end{array}$ & 0.022 \\
\hline \multicolumn{5}{|l|}{ HBsAg status } \\
\hline $\begin{array}{l}\text { Positive } \\
\text { Negative }\end{array}$ & $\begin{array}{l}72 \\
48\end{array}$ & $\begin{array}{l}19(26.4 \%) \\
10(20.8 \%)\end{array}$ & $\begin{array}{l}53(73.6 \%) \\
38(79.2 \%)\end{array}$ & 0.486 \\
\hline \multicolumn{5}{|c|}{ Tumor differentiation } \\
\hline $\begin{array}{l}\text { High } \\
\text { Moderate } \\
\text { Poor }\end{array}$ & $\begin{array}{l}43 \\
44 \\
33\end{array}$ & $\begin{array}{l}12(27.9 \%) \\
9(20.5 \%) \\
8(24.2 \%)\end{array}$ & $\begin{array}{l}31(72.1 \%) \\
35(79.5 \%) \\
25(75.8 \%)\end{array}$ & 0.715 \\
\hline \multicolumn{5}{|l|}{ Cirrhosis } \\
\hline $\begin{array}{l}\text { Yes } \\
\text { No }\end{array}$ & $\begin{array}{l}73 \\
47\end{array}$ & $\begin{array}{l}17(23.3 \%) \\
12(25.5 \%)\end{array}$ & $\begin{array}{l}56(76.7 \%) \\
35(74.5 \%)\end{array}$ & 0.781 \\
\hline \multicolumn{5}{|l|}{ Serum AFP } \\
\hline $\begin{array}{l}<200 \mathrm{ng} / \mathrm{dl} \\
\geq 200 \mathrm{ng} / \mathrm{dl}\end{array}$ & $\begin{array}{l}68 \\
52\end{array}$ & $\begin{array}{l}20(29.4 \%) \\
9(17.3 \%)\end{array}$ & $\begin{array}{l}48(70.6 \%) \\
43(82.7 \%)\end{array}$ & 0.106 \\
\hline \multicolumn{5}{|l|}{ Recurrence* } \\
\hline $\begin{array}{l}\text { Yes } \\
\text { No }\end{array}$ & $\begin{array}{l}34 \\
86\end{array}$ & $\begin{array}{l}8(23.5 \%) \\
21(24.4 \%)\end{array}$ & $\begin{array}{l}26(76.5 \%) \\
65(75.6 \%)\end{array}$ & 0.918 \\
\hline \multicolumn{5}{|l|}{ TNM stage } \\
\hline $\begin{array}{l}\text { I } \\
\text { II } \\
\text { II } \\
\text { IV }\end{array}$ & $\begin{array}{l}18 \\
32 \\
40 \\
30\end{array}$ & $\begin{array}{l}7(38.9 \%) \\
12(37.5 \%) \\
6(15 \%) \\
4(13.3 \%)\end{array}$ & $\begin{array}{l}11(61.1 \%) \\
20(62.5 \%) \\
34(85 \%) \\
26(86.6 \%)\end{array}$ & 0.021 \\
\hline
\end{tabular}

Notes: Bold fonts indicate Statistically significant. Recurrence*:follow-up time for five years after therapeutic surgery.

PCAT-14 inhibits miR-372 expression in HCC by inducing methylation of CpG islands in miR-372 promoter

To investigate the relationship between PCAT-14 and miR-372, we evaluated the expression of miR372 in three HCC cell lines (SMMC7721, HepG2, and HCCLM3) transfected with either pcDNA-PCAT-14 or si-PCAT-14. As shown in Figure 5C, the expression of
miR-372 was inhibited in SMMC7721 cells when PCAT14 was overexpressed $(P<0.01)$. In contrast, PCAT-14 silencing promoted miR-372 expression in HepG2 and HCCLM3 cells (Figure 5D, 5E, $P<0.01$ ). We have previously demonstrated that aberrant DNA methylation of $\mathrm{CpG}$ islands upstream of the miR-372 promoter induces epigenetic silencing of miR-372 in HCC cells [22]. To explore the mechanisms of the negative miR-372 regulation by PCAT-14, we analyzed the levels of three 
Table 2: COX regeression regression analysis on the relationship of clinicopathologic characteristics and prognosis

\begin{tabular}{lcccccc}
\hline Characteristics & \multicolumn{3}{c}{ Univariate } & \multicolumn{3}{c}{ Multivariate } \\
\cline { 2 - 6 } & HR & CI(95\%) & $\boldsymbol{P}$ & HR & CI(95\%) & $\boldsymbol{P}$ \\
\hline PCAT-14 & 1.811 & $1.321-2.403$ & 0.009 & 1.765 & $1.110-2.736$ & 0.012 \\
Age & 0.982 & $0.671-1.437$ & 0.924 & & & \\
Gender & 1.113 & $0.729-1.698$ & 0.620 & & & \\
Tumor stage & 1.098 & $0.810-1.488$ & 0.547 & & & \\
Tumor differentiation & 1.080 & $0.800-1.456$ & 0.616 & & & \\
Metastasis & 1.942 & $1.319-2.861$ & 0.001 & 1.711 & $1.098-2.654$ & \\
Tumor size & 1.334 & $0.896-1.986$ & 0.156 & & & 0.007 \\
Serum AFP & 2.280 & $1.482-3.505$ & 0.0001 & 1.983 & $1.245-3.092$ & \\
Cirrhosis & 1.310 & $0.894-1.921$ & 0.166 & & & \\
\hline
\end{tabular}

Notes: Bold fonts indicate Statistically significant.

active DNA methyltransferases (DNMT1, DNMT3a, and DNMT3b) in HCC cells by qRT-PCR when PCAT14 was aberrantly expressed. The expression of DNMT1, DNMT3a, and DNMT3b was increased when PCAT-14 was overexpressed (Figure 5F, $P<0.01$ ). An opposite result was observed when PCAT-14 was knocked-down (Figure 5G, $P<0.01$ ), suggesting that PCAT-14 might regulate miR-372 methylation. In addition, MSP analysis showed that PCAT-14 overexpression promotes the methylation of miR-372 CpG islands in SMMC7721
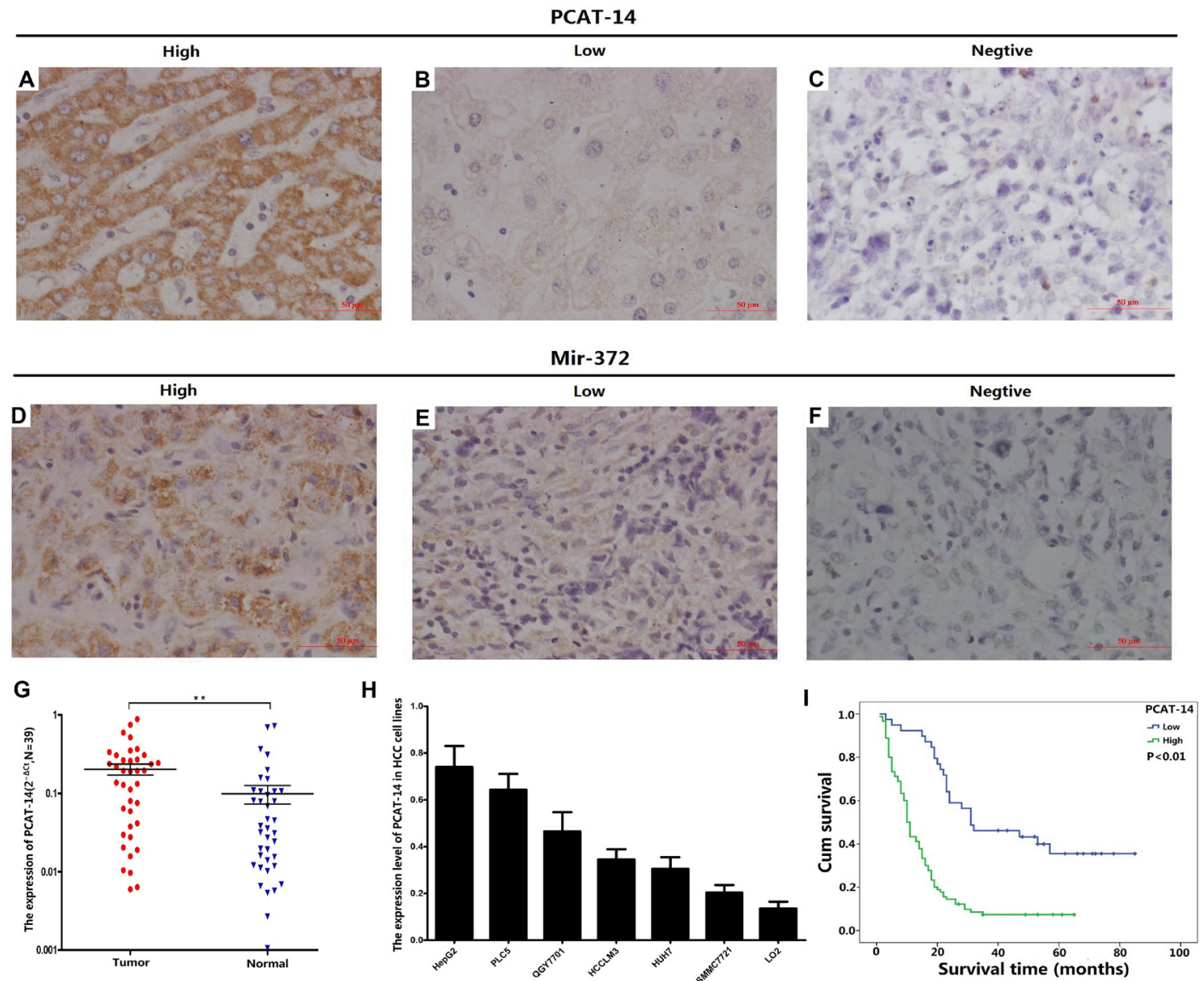

Figure 1: (A-C) The expression of PCAT-14 by in situ hybridization; (D-F) The expression of miR-372 by in situ hybridization; (G) The expression of PCAT-14 by qRT-PCR in 39 HCC patients $(P<0.01)$; $(\mathbf{H})$ The expression of PCAT-14 in HCC cell lines; (I) Overall survival of HCC patients in relation to PCAT-14 expression according to in situ hybridization in 120 HCC patients. Survival of HCC patients with high PCAT-14 expression versus low expression $(P<0.01)$. 
Table 3: Correlation analysis between PCAT-14 and miR-372 expression according to in situ hybridization in 120 patients with $\mathrm{HCC}$

\begin{tabular}{lccccc}
\hline & PCAT-14 (0) & PCAT-14 (1+) & PCAT-14 (2+) & PCAT-14 (3+) & P \\
\hline miR-372 (0) & 1 & 2 & 13 & 17 & $<0.01$ \\
$\operatorname{miR}-372(1+)$ & 1 & 3 & 30 & 20 & - \\
$\operatorname{miR}-372(2+)$ & 3 & 7 & 3 & 3 & - \\
$\operatorname{miR}-372(3+)$ & 4 & 8 & 4 & 1 & - \\
\hline
\end{tabular}

Notes: Bold fonts indicate Statistically significant.

cells, while PCAT-14 suppression inhibits the $\mathrm{CpG}$ islands methylation in HepG2 and HCCLM3 cells (Figure 5C-5E). Together, these findings indicate that in HCC, PCAT-14 inhibits miR-372 expression through inducing methylation of $\mathrm{CpG}$ islands in the miR-372 promoter.

\section{PCAT-14 regulates HCC cell proliferation and invasion depending on miR-372}

Next, we investigated the miR-372 effect on PCAT-14 expression, proliferation, cell cycle, and invasion of HCC cells. SMMC7721 and HepG2 cells were transfected with pcDNA-NC, pcDNA-PCAT-14, pcDNA$\mathrm{NC}+$ miR372 mimic, pcDNA-PCAT-14+miR-372mimic, pcDNA-NC+anti-miR-372, pcDNA+anti-miR-372 or si-NC, si-PCAT-14, si-NC+miR-372 mimic, si-PCAT14+miR-372 mimic, si-NC+anti-miR-372, or si-PCAT14+anti-miR-372. First, we assessed the proliferation of SMMC7721 and HepG2 cells using an MTT assay. We found that miR-372 mimic and anti-miR-372 could suppress the effect of pcDNA-PCAT-14 or si-PCAT-14 in SMMC7721 or HepG2 cells (Figure 6A, 6B). Similar results were obtained when the cell proliferation was analyzed by a clonal colony-forming assay (Figure 6C, 6D). Cell cycle analysis using PI staining indicated that miR-372 overexpression or suppression could eliminate the effect of PCAT-14 on G1/S phase in SMMC7721 or HepG2 cells (Figure 6E, 6F). In addition, trans-well assay indicated that miR-372 could block the influence of PCAT14 on cellular invasion and migration (Figure 2C, 2D). These results suggest that PCAT-14 regulates HCC cell proliferation, cycle, and invasion depending on miR-372.

\section{PCAT-14 regulates ATAD2 expression and activation of Hedgehog pathway via miR-372}

We have previously shown that ATAD2 is one of target genes of miR-372, and that ATAD2 regulates the Hedgehog pathway (Hh pathway) to influence HCC cell proliferation and metastasis $[25,26]$. To investigate the role of PCAT-14 in the regulation of ATAD2 and the Hh pathway, we transfected pcDNA, pcDNA-PCAT-14, pcDNA-PCAT-14+miR-372 mimic or si-NC, si-PCAT-14, or si-PCAT-14+anti-miR-372 in SMMC7721 or HepG2 cells. Gene and protein levels of ATAD2 and Hh pathway key proteins (PTCH1, SMO, Gli2) were analyzed by qRTPCR and western blotting, respectively. Overexpression of PCAT-14 increased the expression of ATAD2, PTCH1, SMO, and Gli2 in SMMC7721 cells, and miR-372 mimic reversed the effect. In HepG2 cells, suppression of PCAT14 inhibited the expression of ATAD2, PTCH1, SMO, and Gli2, and anti-miR-372 eliminated the regulation (Figure 7A-7D). These findings indicate that in HCC cells, PCAT-14 regulates ATAD2 expression and Hh activation via $\mathrm{miR}-372$.

\section{DISCUSSION}

LncRNAs can regulate protein-coding genes, transcription, and post-transcription, and play important roles in biological processes [25, 26]. Many functions of lncRNAs in biological processes have been proposed, including cardiovascular diseases, inflammatory responses, and cancers [27, 28]. These roles are mediated by epigenetic regulation, and transcriptional and posttranscriptional regulation [29]. A number of lncRNAs have been identified in HCC, such as H19, HOTAIR, MALAT1, and MEG3 [30, 31].

PCAT-14 was first reported in prostate cancer. Down-regulation of PCAT-14 in prostate cancer has been associated with an increased probability of metastatic progression and mortality across multiple independent datasets and ethnicities [20]. In-vitro data confirmed that low PCAT-14 expression increases migration of prostate cancer cells, while overexpression of PCAT-14 reduces their growth, migration, and invasion [20,21]. The above studies suggested that PCAT-14 suppresses development of prostate cancer. However, the function and regulation of PCAT-14 in HCC remained unknown.

In this study, we found a negative correlation between PCAT-14 and miR-372 in HCC tissues. We have previously shown that aberrantly high DNA methylation in the miR-372 gene promoter induces epigenetic silencing of miR-372 in HCC and that miR-372 inhibits cancer cell proliferation and invasion. Thus, we speculated that PCAT-14 might regulate the expression of miR-372, thus regulating HCC cell invasion and proliferation. It has been reported that lncRNAs could adjust the methylation status of target genes, such as LncRNA PVT1 regulates prostate cancer cell growth by inducing methylation of miR-146a, LncRNA DBCCR1-003 regulates methylation of DBCCR1 
A
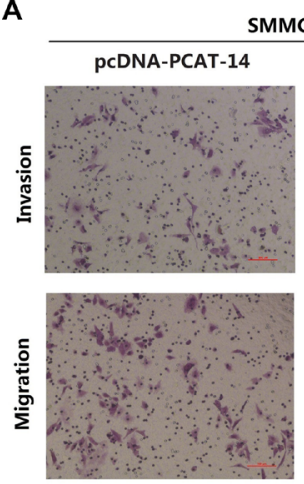

C

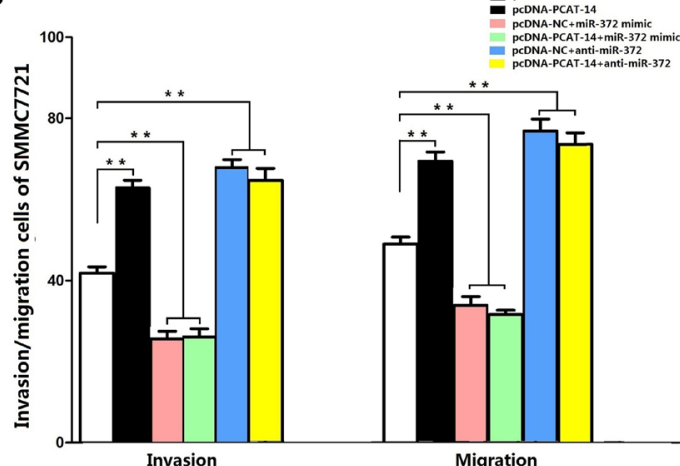

B
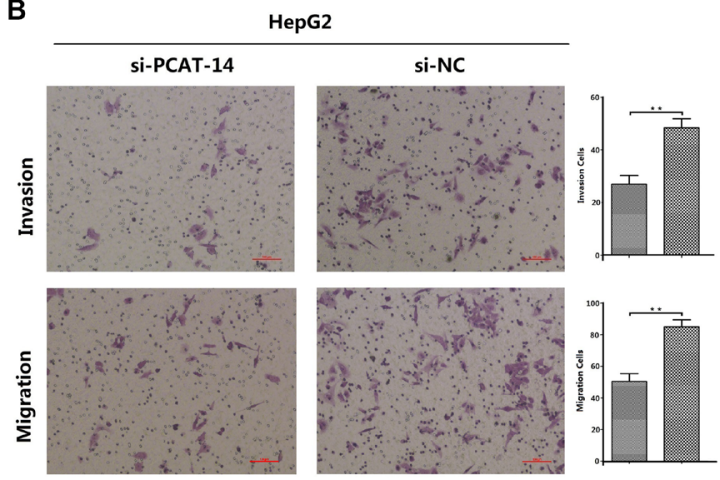

D

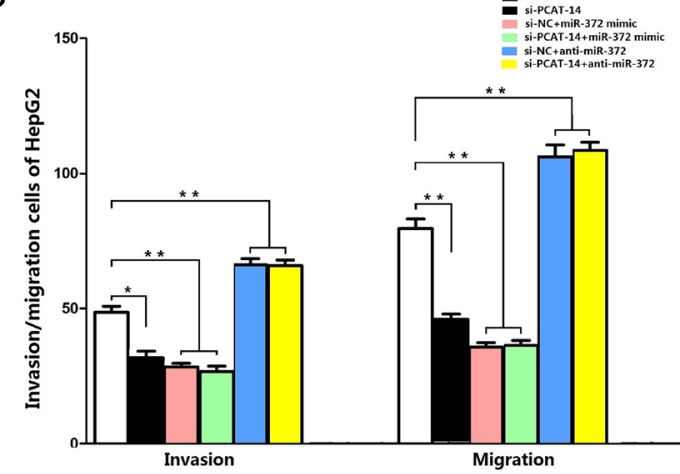

Figure 2: (A) Transwell assays of SMMC7721 cells transfected with pcDNA-PCAT-14 and pcDNA-NC:PCAT-14 up-regulation had a acceleration effect on cell invasion and migration in SMMC7721 cells $(P<0.01)$; (B) Transwell assays of HepG2 cells transfected with si-PCAT-14 and si-NC:PCAT-14 konckdown had a measurable inhibitory effect on cell invasion and migration in HepG2 cells $(P<0.01)$; (C) Transwell assays of SMMC7721 cells transfected with pcDNA-NC,pcDNA-PCAT-14,pcDNA-NC+miR-372 mimic,pcDNAPCAT-14+miR-372 mimic,pcDNA-NC+anti-miR-372,pcDNA-PCAT-14+anti-miR-372:miR-372 could eliminate the effect of PCAT-14 overexpression on invasion and migration in SMMC7721 cells $(P<0.01)$; (D) Transwell assays of HepG2 cells transfected with si-NC,siPCAT-14,si-NC+miR-372 mimic,si-PCAT-14+miR-372 mimic,si-NC+anti-miR-372,si-PCAT-14+anti-miR-372:miR-372 could eliminate the effect of PCAT-14 knockdown on invasion and migration in HepG2 cells $(P<0.01)$.

A

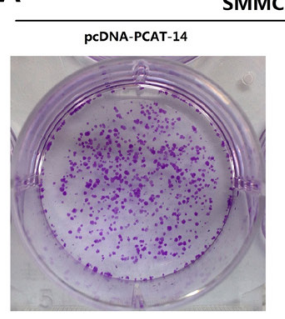

C

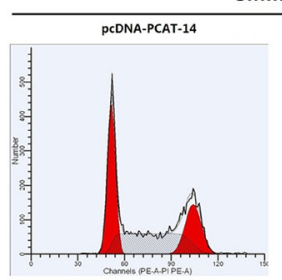

SMMC7721

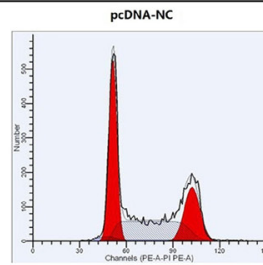

PCDNA-NC
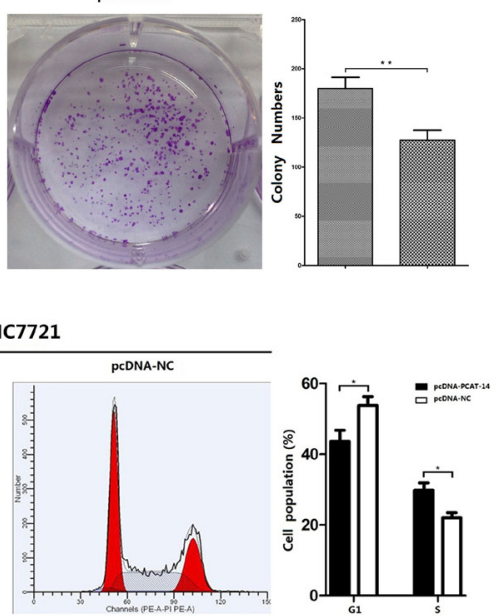

B
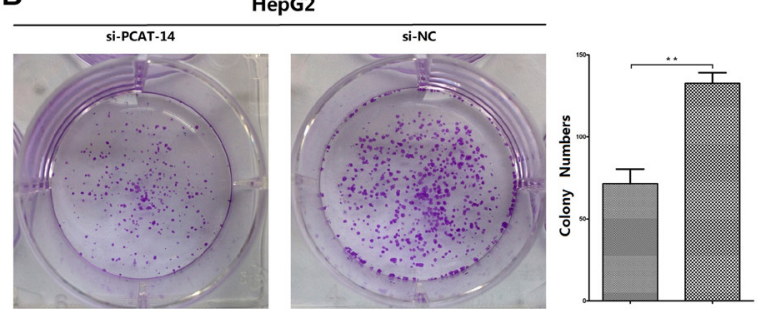

D

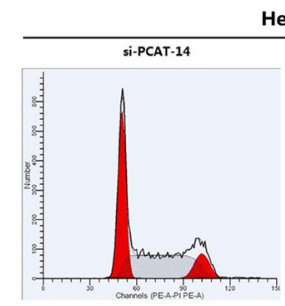

HepG2

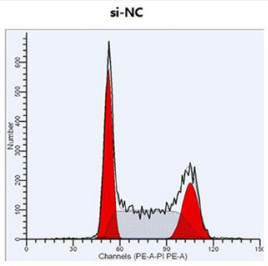

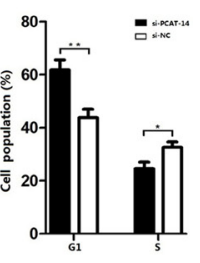

Figure 3: (A) Clonogenic assays were performed with SMMC7721 cells. The number of colonies formed by cells treated with pcDNAPCAT-14 was more than that of pcDNA-NC-treated cells $(P<0.01)$; (B) Clonogenic assays were performed with HepG2 cells. The number of colonies formed by cells treated with si-PCAT-14 was fewer than that of si-NC-treated cells $(P<0.01)$; (C) In SMMC7721 cells,PCAT14-overexpressed cells showed an decrease in the number of cells in G1 phase (40.18\%) and S phase (27.44\%) compared with the negative control (G1, 56.52\%; S, 20.64\%,P<0.05); (D) In HepG2 cells, PCAT-14 lowexpression showed an increase in the number of cells in G1 phase $(62.46 \%)$ and $\mathrm{S}$ phase $(21.09 \%)$ compared with the negative control $(\mathrm{G} 1,43.42 \% ; \mathrm{S}, 29.92 \%, P<0.01)$. 
via DNMT1 in bladder cancer, and LncRNA RP5-833A20.1 induces methylation of NFIA in U251 cells [32-34]. To investigate the relationship between PCAT-14 and miR372 in HCC, we evaluated the expression of miR-372 in three HCC cancer cell lines (SMMC7721, HepG2, and HCCLM3) transfected with either pcDNA-PCAT-14 or siPCAT-14. Results showed that overexpression of PCAT-14 inhibited miR-372 expression and suppression of PCAT-14
A

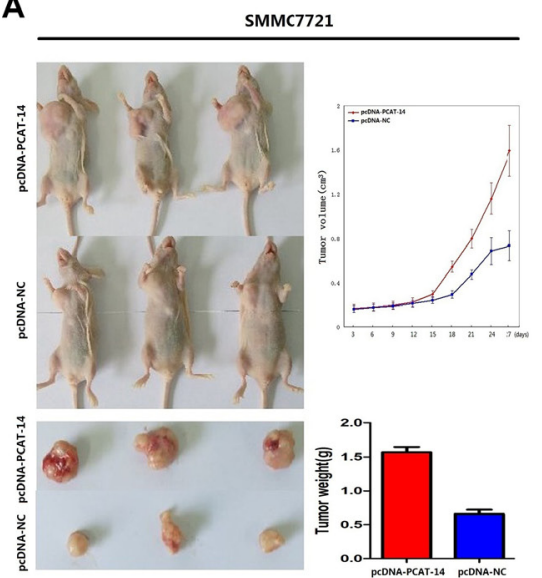

B

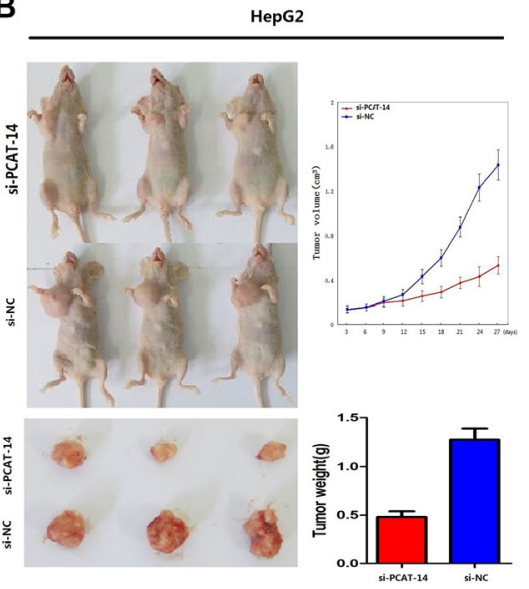

C

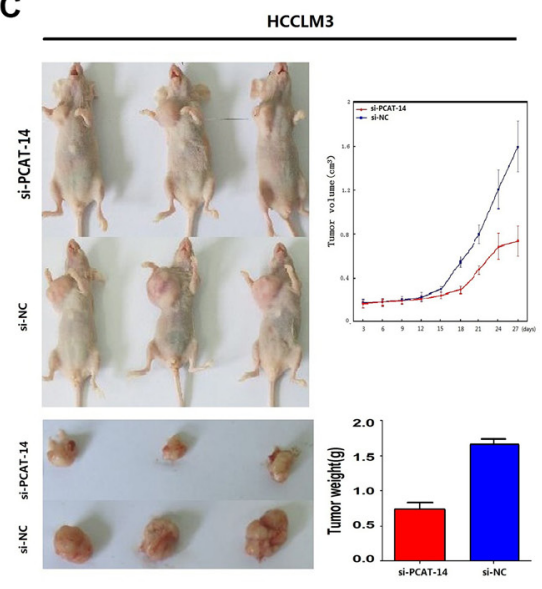

Figure 4: (A) Twenty-eight days after the mice were injected with SMMC7721 transfected by pcDNA-PCAT-14,the weight of the tumors were much higher than pcDNA-NC group $(P<0.01)$; (B) The weight of tumors in nude mice injected with HepG2 transfected by siPCAT-14 were lower than si-NC group $(P<0.01)$; $(\mathbf{C})$ The weight of tumors in nude mice injected with HCCLM3 transfected by siPCAT-14 were lower than si-NC group $(P<0.01)$.
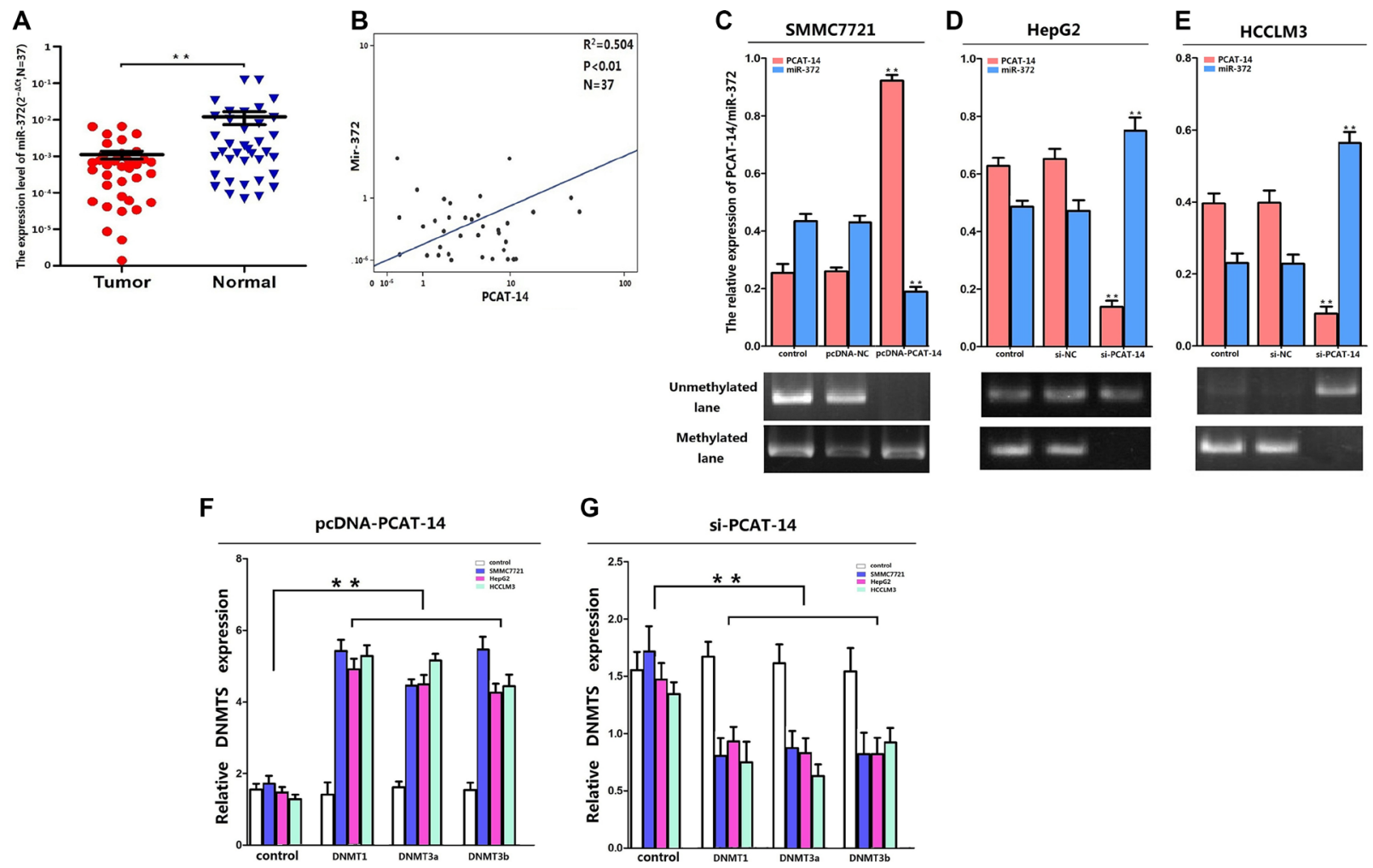

Figure 5: (A) The results of qRT-PCR showed miR-372 was lowexpressed $(P<0.01)$ in HCC tissue samples; (B) The expression levels of PCAT-14 and miR-372 were negative correlation by linear regression analysis accroading to the results of qRT-PCR in 37 HCC tissue samples $\left(\mathrm{R}^{2}=0.504, P<0.01\right)$; $(\mathbf{C})$ The expression of miR-372 was significantly inhibited in SMMC7721 when PCAT-14 was overexpressed $(P<0.01)$ and MSP analysis showed PCAT-14 overexpression promoted the methylation of miR-372 CpG islands in SMMC7721 cells; (D, E) PCAT-14 silencing markedly promoted miR-372 expression $(P<0.01)$ and inhibited the CpG islands methylation in HepG2 and HCCLM3 cells; (F, G) The expression levels of DNMT1, DNMT3a, and DNMT3b were obviously increased when PCAT-14 was overexpressed $(P<0.01)$ and the contrary result was observed when PCAT-14 was knocked-down $(P<0.01)$. 

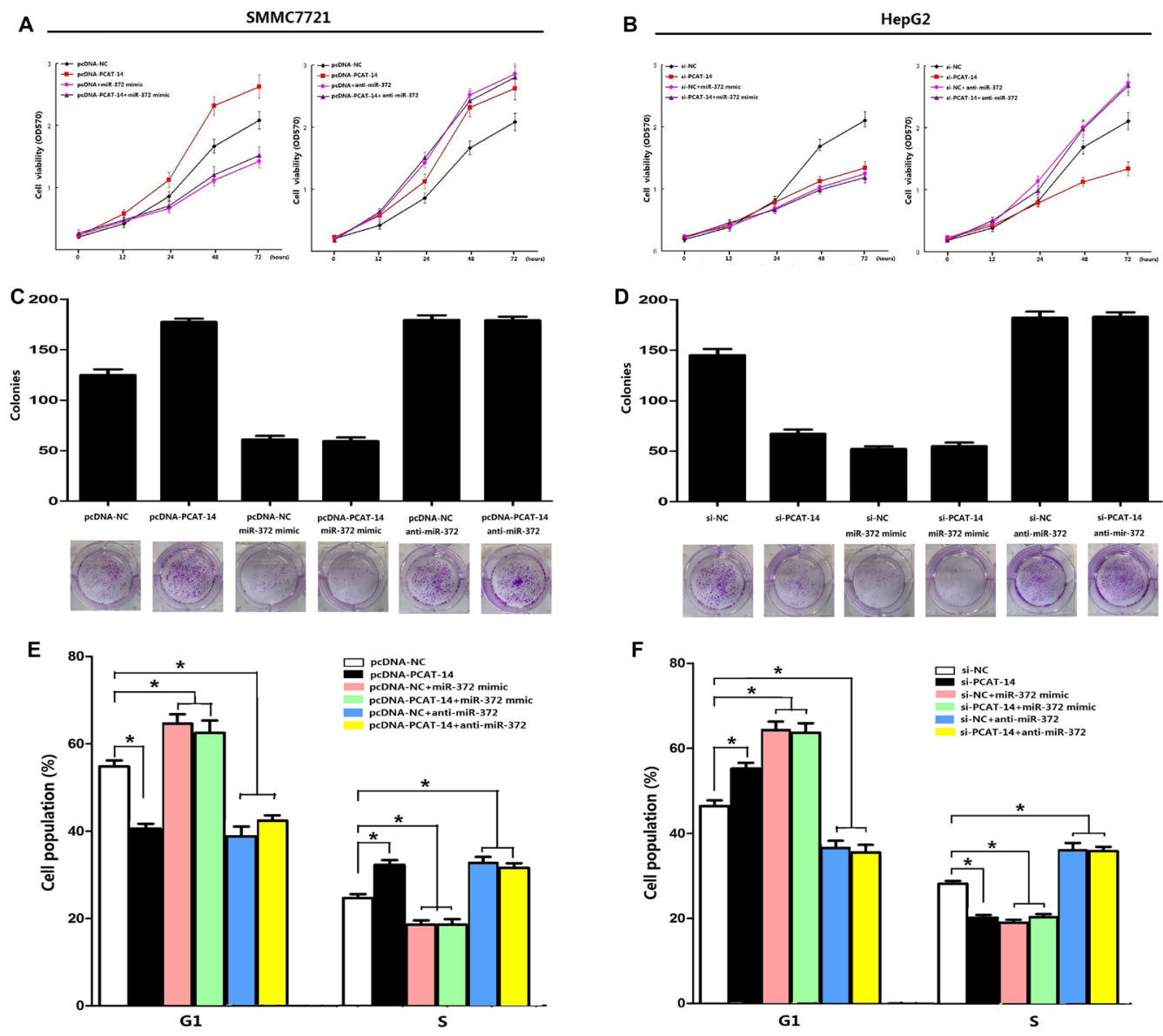

Figure 6: (A, B) A significant change in the proliferation rate was observed with the MTT assay 72 hours after transfection with pcDNAPCAT-14 or si-PCAT-14 when compared to pcDNA-NC or si-NC in SMMC7721 or HepG2 cells respectively $(P<0.01)$ and miR-372 could block up the influence; $(\mathbf{C}, \mathbf{D})$ Clonal colony-forming assay showed miR-372 could eliminate the effect of PCAT-14 on colonyforming ability in SMMC7721 and HepG2 cells. (E, F) Flow cytometry analysis by PI staining indicated that miR-372 overexpression or lowexpression could eliminated the effect of PCAT-14 up-regulated or knockdown on G1/S phase in SMMC7721 or HepG2 cells.

A SMMC7721

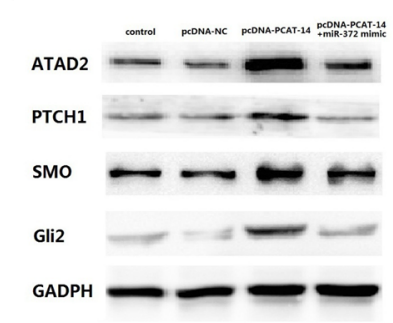

B
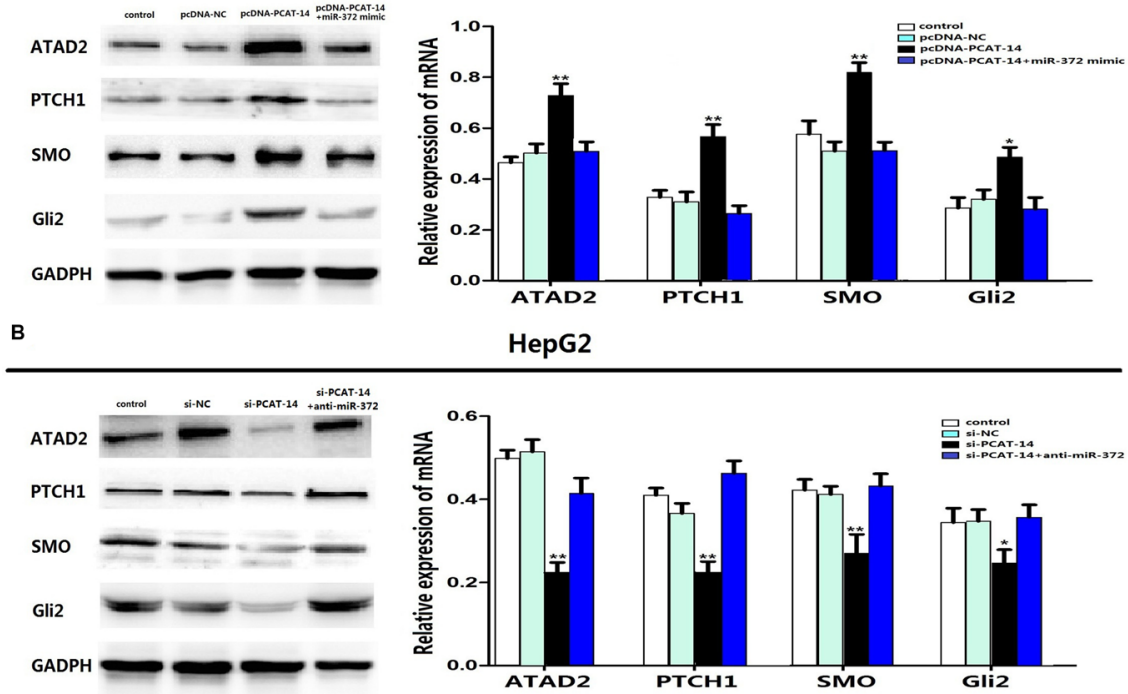

Figure 7: (A) Overexpression of PCAT-14 could up-regulated the expression of ATAD2,PTCH1,SMO,Gli2 in SMMC7721 cells and miR-372 mimic could eliminate the regulation. (B) In HepG2 cells, lowexpression of PCAT-14 could down-regulated the expression of ATAD2,PTCH1,SMO,Gli2 and anti-miR-372 could eliminate the regulation. 
elevated miR-372 expression. To explore the mechanisms of the negative regulation of miR-372 by PCAT-14, we analyzed the levels of three active DNA methyltransferases (DNMT1, DNMT3a, and DNMT3b) in HCC cells aberrantly expressing PCAT-14. The results demonstrated that PCAT-14 could up-regulate the expression of DNMT1, DNMT3a, and DNMT3b, suggesting that PCAT-14 might regulate miR-372 methylation. In addition, MSP analysis provided evidence that PCAT-14 overexpression promotes the methylation of miR-372 CpG islands in SMMC7721 cells, and PCAT-14 suppression inhibits the $\mathrm{CpG}$ islands methylation in HepG2 and HCCLM3 cells. Together, these findings indicate that in HCC cells, PCAT-14 inhibits the miR-372 expression through inducing the methylation of $\mathrm{CpG}$ islands in its promoter. Furthermore, our results show that miR-372 overexpression or downregulation can eliminate the effect of PCAT-14 on cell proliferation, invasion, and cell cycle in SMMC7721 and HepG2 cells, suggesting that PCAT-14 regulates the HCC carcinogenesis depending on miR-372.

The ATPase family AAA domain-containing protein 2, ATAD2, is highly expressed in several types of tumors, such as breast cancer, lung cancer, and large B-cell lymphoma [35-40]. ATAD2 is one of the target genes of miR-372, and regulates the Hh pathway to influence HCC cell proliferation and metastasis $[23,24]$. To investigate the role of PCAT-14 in ATAD2 and Hh signaling, we altered the expression of PCAT-14 in SMMC7721 and HepG2 cells, and evaluated gene and protein levels of ATAD2 and Hh pathway key proteins (PTCH-1, SMO, and Gli2). Results showed that PCAT-14 could promote the expression of ATAD2, PTCH-1, SMO, and Gli2, while miR-372 could inhibit them, suggesting that PCAT-14 regulates the ATAD2 expression and Hedgehog pathway via miR-372.
In summary, here we demonstrate the function of PCAT-14 in HCC carcinogenesis by providing the following experimental evidence (Figure 8). 1) HCC tissues and cells express high levels of PCAT-14, which promotes HCC cell proliferation and invasion. 2) PCAT-14 inhibits miR-372 expression by inducing the methylation of $\mathrm{CpG}$ islands in the miR-372 promoter. 3) PCAT-14 regulates HCC cell growth and invasion depending on miR-372. 4) ATAD2 is one of the target genes of miR-372, and regulates the $\mathrm{Hh}$ pathway to influence HCC proliferation and metastasis. 5) PCAT-14 regulates ATAD2 expression and Hedgehog pathway via miR-372. Together, these findings indicate that PCAT-14 plays an important role in HCC carcinogenesis and may provide a new target for $\mathrm{HCC}$ detection and treatment. Future studies should determine the precise mechanisms of the aberrant expression of PCAT-14 in HCC.

\section{MATERIALS AND METHODS}

\section{Patient tissue samples and liver cancer cell lines}

HCC tissue slice samples were obtained from 120 patients (51 males and 69 females) diagnosed with HCC who had undergone a routine hepatic resection in the First Affiliated Hospital of China Medical University between January 2007 and January 2009 [22]. The follow-up period for survivors was 5 years. None of the patients had received preoperative radiotherapy or chemotherapy prior to surgical resection. A total of 37 paired fresh specimens, including both tumor tissues and the corresponding paired noncancerous parenchyma, were snap-frozen in liquid nitrogen and stored at $-70^{\circ} \mathrm{C}$ immediately after resection until processing. Histological diagnosis and differentiation

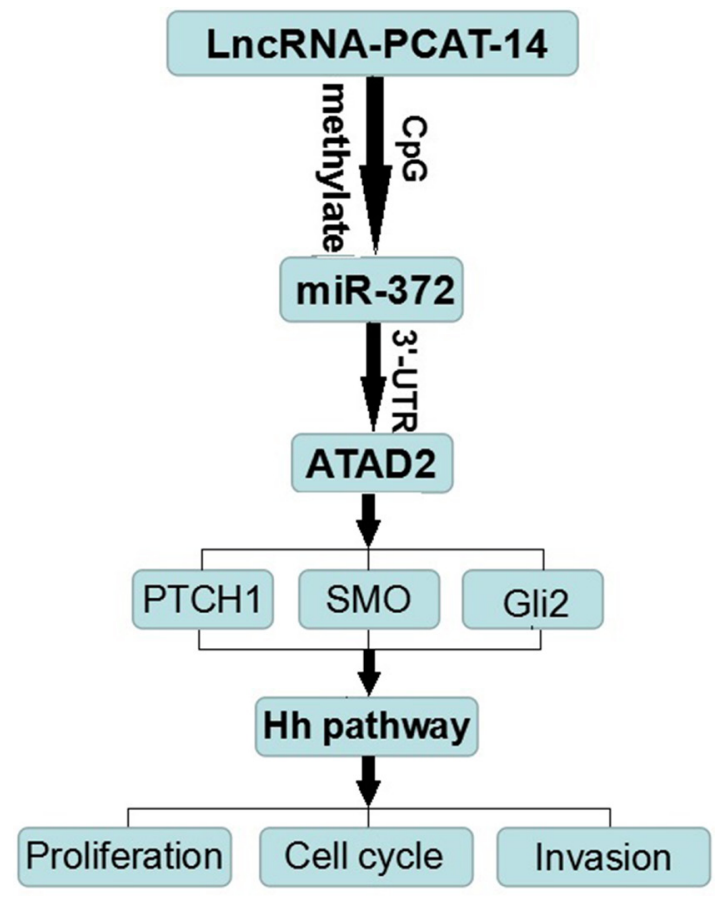

Figure 8: The molecular mechanism of PCAT-14 action in HCC carcinogenesis. 
were evaluated independently by three pathologists according to the WHO classification system [41]. The project protocol was approved by the Institutional Ethics Committee of China Medical University prior to the initiation of the study. All patients provided written informed consent for the use of the tumor tissues for clinical research. The liver cancer cell lines Huh7, HCCLM3, HepG2, SMMC7721, PLC5, and QGY7701 and the normal liver cell line LO2 were obtained from Shanghai Cell Bank (Shanghai, China).

\section{RNA preparation and quantitative real-time PCR}

Total RNA was extracted from approximately 100 $\mathrm{mg}$ of the 37 paired tissue samples and liver cancer cell lines using TRIzol reagent ( Invitrogen Company, USA) according to the manufacturer's instructions. The PCAT14 primers were purchased from Takara Company (Japan). The GADPH gene was used as a reference control for PCAT-14. The relative gene expression was expressed as $\Delta \mathrm{Ct}=\mathrm{Ct}$ gene - $\mathrm{Ct}$ reference and the fold change in gene expression was calculated using the $2^{-\Delta \Delta \mathrm{Ct}}$ method [42].

\section{Western blot}

Cells were washed with ice-cold PBS and lysed by RIPA (Beyotime, China) containing protease inhibitors (Beyotime, China). Protein lysates were separated in 10 $\%$ SDS-PAGE and transferred onto PVDF membrane (Millipore, USA). The membranes were blocked by $5 \%$ skim milk in TBST buffer, and incubated with primary antibodies for ATAD2, PTCH1, SMO, and Gli2 (Abcam, UK) overnight at $4^{\circ} \mathrm{C}$. PVDF membranes were washed in TBST and incubated with horseradish peroxidase-conjugated secondary antibodies (ProteinTech Group, USA). Antibody against GAPDH (Cell Signaling Technology, USA) was used as an internal control. Proteins were visualized using ECL Western blotting substrate (Pierce, USA).

\section{In situ hybridization}

The in situ hybridization kit was purchased from Boster Company (Wuhan, China) and used according to the manufacturer's instructions. Briefly, the tissue slides were hybridized with $20 \mathrm{ul}$ of 5'-digoxigenin (DIG) LNAmodified-PCAT-14-3p. Results were independently scored by two experienced pathologists. The scoring of positive tumor cells was as follows: $0(0 \%), 1$ (1-10\%), 2 (11$50 \%), 3(51-80 \%)$ and $4(>80 \%)$. The staining intensity was visually scored as follows: 0 (negative), 1 (weak), 2 (moderate) and 3 (strong). The PCAT-14 expression score was calculated from the value of percent positivity score multiplied by the staining intensity score. This value ranged from 0 to 12 , and the tumors were classified as follows: negative $(-)$, score 0 ; lower expression $(1+)$, score 1-4; moderate expression $(2+)$, score 5-8; and strong expression $(3+)$, score 9-12. In situ hybridization
PCAT-14 staining was grouped into two categories: low expression $(0 / 1+)$ and high expression $(2+/ 3+)$.

\section{Cell transfection}

SMMC-7721 cells were transfected with pcDNAlincRNA-PCAT-14 for overexpressing PCAT-14, and HepG2 cells were transfected with si-lincRNA-PCAT-14 for suppression of PCAT-14 using DharmaFECT Transfection Reagent (GE Healthcare, Little Chalfont, Buckinghamshire, UK) according to manufacturer's instructions. The pcDNA-NC and si-NC acted as negative controls, respectively. The pcDNA-lincRNAPCAT-14, pcDNA-NC, si-lincRNA-PCAT-14 and si-NC were synthesized by Life Technology (Beijing, China). miR-372 mimic or anti-miR-372 (both purchased from Shanghai Genepharma Company) were transfected using Lipofectamine $^{\circledR}$ RNAiMAX Reagent (Invitrogen, USA) according to the manufacturer's instructions.

\section{Cell cycle analysis}

SMMC-7721 or HepG2 cells seeded at a density of $5 \times 105$ per well in 6 -well plates were transfected with pcDNA-lincRNA-PCAT-14 or si-lincRNA-PCAT-14. After $48 \mathrm{~h}$, cells were trypsinized, fixed with $70 \%$ ethanol at $4^{\circ} \mathrm{C}$, and washed with PBS. RNase A $(100 \mu \mathrm{L})$ was added, and the mixture was incubated in a $37^{\circ} \mathrm{C}$ water bath for $30 \mathrm{~min}$. Next, $400 \mu \mathrm{L}$ of PI staining solution was added and samples were incubated at $4^{\circ} \mathrm{C}$ in the dark for $30 \mathrm{~min}$; a computer was then used to detect and record the red fluorescence upon excitation at a wavelength of $488 \mathrm{~nm}$.

\section{MTT assay}

After transfection, 5000 cells/well were seeded in 96-well plates in media containing $10 \% \mathrm{FBS}$ and incubated for $0,24 \mathrm{~h}, 48 \mathrm{~h}, 72 \mathrm{~h}$. On the indicated days, 3- (4,5)-dimethylthiahiazo (-z-y1)-3,5-diphenytetrazoliumromide (MTT) (KyeGEN BioTECH, Nanjing, China) was added into each well according to the manufacturer's instructions, and the cells were incubated for $4 \mathrm{~h}$ at $37^{\circ} \mathrm{C}$. The supernatants were then removed and $150 \mathrm{~mL}$ of DMSO (Sigma-Aldrich, Germany) was added to each well to dissolve the formazan crystals. Absorbance levels were measured at the wavelength of $490 \mathrm{~nm}$ using an automatic microplate reader (Gene, HK). The data derived from triplicate samples are presented as mean \pm s.d.

\section{Colony formation assay}

After transfection, 500 cells were counted and seeded in 6-well plates. The plates were incubated for 10 days, and the cells were fixed by $4 \%$ paraformaldehyde and stained using $0.1 \%$ crystal violet. Colonies were counted only if they included 50 cells at least. Triplicate independent experiments were performed. 


\section{Cell invasion assay}

SMMC-7721 or HepG2 cells were transfected with pcDNA-lincRNA-PCAT-14 or si-lincRNAPCAT-14 for $48 \mathrm{~h}$, and seeded onto a synthetic basement membrane in the inset of a 24-well culture plate. In the invasion assay, polycarbonate filters coated with $50 \mu \mathrm{L}$ Matrigel (1:9, BD Bioscience) were placed in a Transwell chamber (Costar). After incubation, filters were fixed and stained with $0.1 \%$ crystal violet solution. Non-invading cells were removed using a cotton swab, and invading cells on the underside of the filter were counted with an inverted microscope.

\section{Tumorigenicity experiments in nude mice}

Eighty male nude mice weighing 18 to $20 \mathrm{~g}$, provided by Shanghai Laboratory Animal Center (Chinese Academy of Science, China), were bred under aseptic conditions; the animals were housed in an area with a constant humidity of $60-70 \%$ and a room temperature of $18-20^{\circ} \mathrm{C}$. Animal maintenance, husbandry and experimental procedures were performed in accordance with the rules of China Medical University for the Use of Experimental Animals and approved by the Medical Animal Care and Use Committee of China Medical University (Shenyang, China). Mice were separated into four groups: pcDNA-lincRNA-PCAT-14 VS pcDNA-NC; si-lincRNA-PCAT-14 VS si-NC. The corresponding cell groups were administered by a subcutaneous injection $(0.1$ $\mathrm{ml}$ of a solution containing $1 \times 10^{4} \mathrm{cells} / \mathrm{ml}$ ). Mice were examined every 5 days, and sacrificed 28 days after the initial subcutaneous injection. The tumors were resected and weighed.

\section{Authors' contributions}

Yawei Wang and Ye Hu designed the study, performed the experiments,wrote the paper and contributed equally to this work.Wanchuan Zhang, Kaiyu Wang, Yu Liu, Xin Wang, Tiemin Li, Yang Ye, and Yanqing Tang participated in experiments. Gang Wu provided tumor samples and clinical information.All authors read and approved the manuscript.

\section{ACKNOWLEDGMENTS}

This work was supported by a grant from Population and Health Research Projects from Shenyang Science and Technology Bureau (No. F15-139-9-25). This work was supported by a grant from Natural Science Foundation of Liaoning Province (No. 201520529).

\section{CONFLICTS OF INTEREST}

None.

\section{REFERENCES}

1. Llovet JM, Burroughs A, Bruix J. Hepatocellular carcinoma. Lancet. 2003; 362:1907-1917.

2. Jemal A, Bray F, Center MM, Ferlay J, Ward E, Forman D. Global cancer statistics. CA Cancer J Clin. 2011; 61:69-90.

3. Bruix J, Gores GJ, Mazzaferro V. Hepatocellular carcinoma:clinical frontiers and perspectives. Gut. 2014; 63:844-855.

4. Block TM, Mehta AS, Fimmel CJ, Jordan R. Molecular viral oncology of hepatocellular carcinoma. Oncogene. 2003; 22:5093-5107.

5. Feng JT, Shang S, Beretta L. Proteomics for the early detection and treatment of hepatocellular carcinoma. Oncogene. 2006; 25:3810-7.

6. Mercer TR, Dinger ME, Mattick JS. Long non-coding RNAs: insights into functions. Nat. Rev. Genet. 2009; 10:155-159.

7. Ørom UA, Derrien T, Beringer M, Gumireddy K, Gardini A, Bussotti G, Lai F, Zytnicki M, Notredame C, Huang Q, Guigo R, Shiekhattar R. Long noncoding RNAs with enhancer-like function in human cells. Cell. 2010; 143:46-58.

8. Cui X, Jing X, Long C, Tian J, Zhu J. Long noncoding RNA MEG3, a potential novel biomarker to predict the clinical outcome of cancer patients: a meta-analysis. Oncotarget. 2017; 8:19049-56. doi: 10.18632/oncotarget.14987.

9. Peng W, Wu G, Fan H, Wu J, Feng J. Long noncoding RNA SPRY4-IT1 predicts poor patient prognosis and promotes tumorigenesis in gastric cancer. Tumor Biol. 2015; 36:6751-6758.

10. Fotouhi Ghiam A, Taeb S, Huang X, Huang V, Ray J, Scarcello S, Hoey C, Jahangiri S, Fokas E, Loblaw A, Bristow RG, Vesprini D, Boutros P, Liu SK. Long noncoding RNA urothelial carcinoma associated 1 (UCA1) mediates radiation response in prostate cancer. Oncotarget. 2017; 8:4668-89. doi: 10.18632/oncotarget.13576.

11. Li SP, Xu HX, Yu Y, He JD, Wang Z, Xu YJ, Wang CY, Zhang HM, Zhang RX, Zhang JJ, Yao Z, Shen ZY. LncRNA HULC enhances epithelial-mesenchymal transition to promote tumorigenesis and metastasis of hepatocellular carcinoma via the miR-200a-3p/ZEB1 signaling pathway. Oncotarget. 2016; 7:42431-46. doi: 10.18632/ oncotarget.9883.

12. Su DN, Wu SP, Chen HT, He JH. HOTAIR, a long noncoding RNA driver of malignancy whose expression is activated by FOXC1, negatively regulates miRNA-1 in hepatocellular carcinoma. Oncol Lett. 2016; 12:4061-4067.

13. Huang JL, Ren TY, Cao SW, Zheng SH, Hu XM, Hu YW, Lin L, Chen J, Zheng L, Wang Q. HBx-related long noncoding RNA DBH-AS1 promotes cell proliferation and survival by activating MAPK signaling in hepatocellular carcinoma. Oncotarget. 2015; 6:33791-804. doi: 10.18632/ oncotarget.5667. 
14. Prensner JR, Iyer MK, Balbin OA, Dhanasekaran SM, Cao Q, Brenner JC, Laxman B, Asangani IA, Grasso CS, Kominsky HD, Cao X, Jing X, Wang X, et al. Transcriptome sequencing across a prostate cancer cohort identifies PCAT-1, an unannotated lincRNA implicated in disease progression. Nat Biotechnol. 2011; 29:742-749.

15. Prensner JR, Chen W, Han S, Iyer MK, Cao Q, Kothari V, Evans JR, Knudsen KE, Paulsen MT, Ljungman M, Lawrence TS, Chinnaiyan AM, Feng FY. The long noncoding RNA PCAT-1 promotes prostate cancer cell proliferation through cMyc. Neoplasia. 2014; 16:900-908.

16. Wan L, Zhang L, Fan K, Cheng ZX, Sun QC, Wang JJ. Knockdown of Long Noncoding RNA PCAT6 Inhibits Proliferation and Invasion in Lung Cancer Cells. Oncol Res. 2016; 24:161-170.

17. Malik R, Patel L, Prensner JR, Shi Y, Iyer MK, Subramaniyan S, Carley A, Niknafs YS, Sahu A, Han S, Ma T, Liu M, Asangani IA, et al. The lncRNA PCAT29 inhibits oncogenic phenotypes in prostate cancer. Mol Cancer Res. 2014; 12:1081-1087.

18. Yan TH, Yang H, Jiang JH, Lu SW, Peng CX, Que HX, $\mathrm{Lu}$ WL, Mao JF. Prognostic significance of long noncoding RNA PCAT-1 expression in human hepatocellular carcinoma. Int J Clin Exp Pathol. 2015; 8:4126-4131.

19. Wen J, Xu J, Sun Q, Xing C, Yin W. Upregulation of long non coding RNA PCAT-1 contributes to cell proliferation, migration and apoptosis in hepatocellular carcinoma. Mol Med Rep. 2016; 13:4481-4486.

20. White NM, Zhao SG, Zhang J, Rozycki EB, Dang HX, McFadden SD, Eteleeb AM, Alshalalfa M, Vergara IA, Erho N, Arbeit JM, Karnes RJ, Den RB, et al. Multiinstitutional Analysis Shows that Low PCAT-14 Expression Associates with Poor Outcomes in Prostate Cancer. Eur Urol. 2017; 2:257-266.

21. Shukla S, Zhang X, Niknafs YS, Xiao L, Mehra R, Cieślik M, Ross A, Schaeffer E, Malik B, Guo S, Freier SM, Bui HH, Siddiqui J, et al. Identification and Validation of PCAT14 as Prognostic Biomarker in Prostate Cancer. Neoplasia. 2016; 18:489-499.

22. Wu G, Wang Y, Lu X, He H, Liu H, Meng X, Xia S, Zheng K, Liu B. Low mir-372 expression correlates with poor prognosis and tumor metastasis in hepatocellular carcinoma. BMC Cancer. 2015; 15:182.

23. Wu G, Liu H, He H, Wang Y, Lu X, Yu Y, Xia S, Meng X, Liu Y. miR-372 down-regulates the oncogene ATAD2 to influence hepatocellular carcinoma proliferation and metastasis. BMC Cancer. 2014; 14:107.

24. Wu G, Lu X, Wang Y, He H, Meng X, Xia S, Zhen K, Liu Y. Epigenetic high regulation of ATAD2 regulates the $\mathrm{Hh}$ pathway in human hepatocellular carcinoma. Int J Oncol. 2014; 45:351-361.

25. Qiu MT, Hu JW, Yin R, Xu L. Long noncoding RNA: an emerging paradigm of cancer research. Tumor Biology. 2013; 34:613-620.
26. Eades G, Zhang YS, Li QL, Xia JX, Yao Y, Zhou Q. Long non-coding RNAs in stem cells and cancer. World J Clin Oncol. 2014; 5:134-141.

27. Fatica A, Bozzoni I. Long non-coding RNAs: new players in cell differentiation and development. Nat Rev Genet. 2014; 15:7-21.

28. Koch L. Disease genetics: Therapeutic targeting of a long noncoding RNA. Nat Rev Genet. 2015; 16:2.

29. Gibb EA, Brown CJ, Lam WL. The functional role of long noncoding RNA in human carcinomas. Mol Cancer. 2011; 4; $10: 38$.

30. Sun J, Bie B, Zhang S, Yang J, Li Z. Long non-coding RNAs: critical players in hepatocellular carcinoma. Int J Mol Sci. 2014; 15:20434-20448.

31. Lin R, Maeda S, Liu C, Karin M, Edgington TS. A large noncoding RNA is a marker for murine hepatocellular carcinomas and a spectrum of human carcinomas. Oncogene. 2007; 26:851-858.

32. Liu HT, Fang L, Cheng YX, Sun Q. LncRNA PVT1 regulates prostate cancer cell growth by inducing the methylation of miR-146a. Cancer Med. 2016; 12; 5:3512-3519.

33. Qi D, Li J, Que B, Su J, Li M, Zhang C, Yang M, Zhou G, Ji W. Long non-coding RNA DBCCR1-003 regulate the expression of DBCCR1 via DNMT1 in bladder cancer. Cancer Cell Int. 2016; 16:81.

34. Kang CM, Hu YW, Nie Y, Zhao JY, Li SF, Chu S, Li HX, Huang QS, Qiu YR. Long non-coding RNA RP5-833A20.1 inhibits proliferation, metastasis and cell cycle progression by suppressing the expression of NFIA in U251 cells. Mol Med Rep. 2016; 12; 14:5288-5296.

35. Alizadeh AA, Eisen MB, Davis RE, Ma C, Lossos IS, Rosenwald A, Boldrick JC, Sabet H, Tran T, Yu X, Powell JI, Yang L, Marti GE, et al. Distinct types of diffuse large B-cell lymphoma identified by gene expression profiling. Nature. 2000; 2; 3; 403:503-511.

36. Chen X, Cheung ST, So S, Fan ST, Barry C, Higgins J, Lai KM, Ji J, Dudoit S, Ng IO, Van De Rijn M, Botstein D, Brown PO. Gene expression patterns in human liver cancers. Mol Biol Cell 2002, 13:1929-1939.

37. Ma XJ, Salunga R, Tuggle JT, Gaudet J, Enright E, McQuary P, Payette T, Pistone M, Stecker K, Zhang BM, Zhou YX, Varnholt H, Smith B. Gene expression profiles of human breast cancer progression. Proc Natl Acad Sci U S A. 2003; 100:5974-5979.

38. Ramaswamy S, Tamayo $\mathrm{P}$, Rifkin R, Mukherjee S, Yeang CH, Angelo M, Ladd C, Reich M, Latulippe E, Mesirov JP, Poggio T, Gerald W, Loda M, et al. Multiclass cancer diagnosis using tumor gene expression signatures. Proc Natl Acad Sci U S A. 2001; 98:15149-15154.

39. van 't Veer LJ, Dai H, van de Vijver MJ, He YD, Hart AA, Mao M, Peterse HL, van der Kooy K, Marton MJ, Witteveen AT, Schreiber GJ, Kerkhoven RM, Roberts C, et al. Gene expression profiling predicts clinical outcome of breast cancer. Nature. 2002; 1; 31; 415:530-536. 
40. Caron C, Lestrat C, Marsal S, Escoffier E, Curtet S, Virolle V, Barbry P, Debernardi A, Brambilla C, Brambilla E, Rousseaux S, Khochbin S. Functional characterization of ATAD2 as a new cancer/testis factor and a predictor of poor prognosis in breast and lung cancers. Oncogene. 2010; 29:5171-5181.

41. Zhou L, Rui JA, Ye DX, Wang SB, Chen SG, Qu Q. Edmondson-Steiner grading increases the predictive efficiency of TNM staging for long-term survival of patients with hepatocellular carcinoma after curative resection. World J Surg. 2008; 32:1748-1756.

42. Thomsen R, Sølvsten CA, Linnet TE, Blechingberg J, Nielsen AL. Analysis of qPCR data by converting exponentially related $\mathrm{Ct}$ values into linearly related $\mathrm{X} 0$ values. J Bioinform Comput Biol. 2010; 8:885-900. 